\title{
Climate change impacts on rainfed maize yields in Zambia under conventional and optimized crop management
}

\author{
Siatwiinda M. Siatwiinda ${ }^{1,2,3}$ (D) I Iwan Supit ${ }^{2} \cdot$ Bert van Hove $^{2,4} \cdot$ Olusegun Yerokun $^{5}$ • \\ Gerard H. Ros ${ }^{1} \cdot$ Wim de Vries ${ }^{1}$
}

Received: 22 March 2021 / Accepted: 28 July 2021/ Published online: 16 August 2021

(C) The Author(s) 2021

\begin{abstract}
Maize production in Zambia is characterized by significant yield gaps attributed to nutrient management and climate change threatens to widen these gaps unless agronomic management is optimized. Insights in the impacts of climate change on maize yields and the potential to mitigate negative impacts by crop management are currently lacking for Zambia. Using five Global Circulation models and the WOFOST crop model, we assessed climate change impacts on maize yields at a $0.5^{\circ} \times 0.5^{\circ}$ spatial resolution for RCP 4.5 and RCP 8.5 scenarios. Impacts were assessed for the near future (2035-2066) and far future (2065-2096) in comparison with a reference period (1971-2001). The surface temperature and warm days (above $30{ }^{\circ} \mathrm{C}$ ) are projected to increase strongly in the southern and western regions. Precipitation is expected to decline, except in the northern regions, whereas the number of wet days declines everywhere, shortening the growing season. The risk of crop failure in western and southern regions increases due to dry spells and heat stress, while crops in the northern regions will be threatened by flooding or waterlogging due to heavy precipitation. The simulated decline in the waterlimited and water- and nutrient-limited maize yields varied from 15 to $20 \%$ in the near future and from 20 to $40 \%$ in the far future, mainly due to the expected temperature increases. Optimizing management by adjusting planting dates and maize variety selection can counteract these impacts by $6-29 \%$. The existing gaps between water-limited and nutrient-limited maize yields are substantially larger than the expected yield decline due to climate change. Improved nutrient management is therefore crucial to boost maize production in Zambia.
\end{abstract}

Keywords Climate change $\cdot$ Maize $\cdot$ Crop yields $\cdot$ Management $\cdot$ Nutrients and Zambia

Siatwiinda M. Siatwiinda

siatwiinda.siatwiinda@wur.nl

Extended author information available on the last page of the article 


\section{Introduction}

Rainfed agriculture in Sub-Saharan Africa (SSA) is characterized by threats of crop failure due to multiple stresses with the most important ones being climatic conditions and nutrient deficiencies. A balance is needed between achieving food security without degrading the environment by sustainably improving yields in places where yield gaps exist (Foley et al. 2011; Van Ittersum et al. 2016). This is particularly true for maize, being one of the most important staple crops in SSA, used for consumption, livelihoods, and food security (Schlenker and Lobell 2010). In Zambia, as in many countries in SSA, maize is commonly grown by rainfall-dependent smallholder farmers affecting both the national economy and household food security (Arslan et al. 2015; Love et al. 2006; Schlenker and Lobell 2010). In 2017, maize was harvested from 1.4 million hectares of arable land (Faostat 2020) within highly variable farming systems across Zambia (Dradri 2005).

In Zambia, substantial yield gaps exist between water-limited (Yw) and actual yields (Ya) (Chikowo 2016). Existing yield gaps are mainly due to nutrient management. However, climate variability and change threatens to exacerbate yield gaps and increase inter-annual yield variability (Kotir 2011; Ray et al. 2015) in particular due to changes in temperature and precipitation (Challinor et al. 2014; Hoffman et al. 2018; Lobell et al. 2011a; Makondo and Thomas 2020; Peichl et al. 2019; Rurinda et al. 2015; Warnatzsch and Reay 2020). Since changes in temperature and rainfall intensity will vary on both temporal and spatial scale, it is important to have spatially explicit insights into their impact on crop production (Liu et al. 2012; Rurinda et al. 2015). Understanding maize yield responses to climatic changes and impact of adaptation measures is key to a climate-resilient maize cultivation (Becsi et al. 2020; Lobell and Burke 2008).

Understanding the spatiotemporal impacts of climate change is useful, because it facilitates region-specific knowledge for policy and adaptation measures or priorities to tackle those impacts (Challinor et al. 2009). For instance, agronomic management such as planting dates, varieties selection, irrigation, and residue management has been evaluated as successful adaptation measures (Brüssow et al. 2019; Challinor et al. 2014; Karapinar and Özertan 2020). In addition, insight in the impacts of climate change on $\mathrm{Yw}$ is also relevant for use in fertilizer recommendations, since the water-limited yield determines crop nutrient requirement (Sherene et al. 2016). Recommended fertilizer doses guided by target yields are usually designed to fulfill this nutrient requirement given soil nutrient thresholds (Sandal et al. 2008; Singh et al. 2004) thereby minimizing adverse environmental impacts due to overfertilization (Xu et al. 2013). Accurate insight into $\mathrm{Yw}$ and the expected changes therein due to climate change is therefore key for governmental fertilizer subsidy programs that focus on optimum fertilizer composition and application guidelines (Chapoto et al. 2016; Xu et al. 2009). Future proof fertilization recommendations require therefore spatially explicit insights in the evolution of water-limited yields.

In addition to nutrient management, it is also important to evaluate the impact of possible adaptation measures such as altering planting dates, crop types, varieties, fertilizer application, irrigation, and other agronomic management practices, given their potential to counteract climate-induced changes in crop yield (Brüssow et al. 2019; Challinor et al. 2014). Studies have shown that temperatures and precipitation changes in the short term can be mitigated by adjusting planting dates and crop variety in China (Liu et al. 2013; Zhao et al. 2015).

Currently, insights in the mitigation potential of the agronomic crop and fertilizer management under expected climate change in Zambia are lacking, in particular for the potential of 
combined management measures. These insights are critical because the response of crops to interaction of climate change and agronomic management varies with location. Therefore, we assessed expected large-scale and long-term changes in maize yields due to climate change and evaluated the yield response to agronomic management using the best combination of varieties and planting dates. These insights provide support to improve management strategies that help maize farmers to cope with upcoming climatic changes. In this study, we take, however, a large scale field-level assessment as a basis for policymaking, and there is a need to contextualize model assessments for decision-making at the farm system level (Silva and Giller 2021), while accounting for the variation over the country (Nissan et al. 2019).

\section{Methods}

\subsection{Overall approach}

This study takes a modeling approach to analyze the potential impacts of climate change and adaptive management on water-limited (Yw) and water- and nitrogen-limited (Yn) maize yields in Zambia under two climate change scenarios. Impacts on yield were evaluated for two time periods (near future: 2035-2066 and far future: 2065-2096) in comparison with a reference period (1971-2001). Our study focused on the relative changes in crop yield potential of maize at the country level, using a $0.5^{\circ} \times 0.5^{\circ}$ spatial resolution.

There is a large variation in Zambia with respect to management practices and soil properties that affect maize yields. Climatic conditions also vary with average annual rainfall ranging from $700 \mathrm{~mm}$ in the south to $1200 \mathrm{~mm}$ in the north and an annual average temperature ranging from ca $15{ }^{\circ} \mathrm{C}$ to $32{ }^{\circ} \mathrm{C}$ (Jain 2007). Lastly, there is regional variation in farming systems, with predominantly smallholders in the south and commercial farms in the north of Zambia, each with different access to water, fertilizers, and manure. These variations have to be accounted for when one aims for an accurate assessment of yield potentials for maize. However, since our study focuses on large-scale relative changes in Yw and Yn over the coming 30-60 years, we aggregated and averaged the variation in management, soils, and climate to a spatial resolution of 0.5 degrees, the resolution of the available climate projection data. This assumption is supported by the fact that the uncertainties arising from the projected climate data likely exceed those from local variation in soil properties and management. To reduce these uncertainties, we used five GCMs ensemble averages to quantify the changes (Dale et al. 2017). We used the model WOFOST for evaluating crop response to changing climatic conditions. Model-related uncertainty given model structure, parameters, and initial conditions is relevant, but has little impact on the predicted relative change in yield potentials, being the focus of this study. The impact of the aforementioned uncertainties is discussed in more detail later.

\subsection{Study area and data aggregation}

Zambia is located in southern Africa between longitudes $21^{\circ} \mathrm{E}$ to $34^{\circ} \mathrm{E}$ and latitude $8^{\circ} \mathrm{S}$ and $18^{\circ} \mathrm{S}$. The country is approximately $725,615 \mathrm{~km}^{2}$ and has a subtropical climate. Three major agroecological regions have been distinguished, called AER I, II, and III (Chikowo 2016; Veldkamp 1987). The climatic projection data used has a $0.5^{\circ} \times 0.5^{\circ}$ spatial resolution (Hempel et al. 2013), and hence, the country was divided into those grid cells for model 
calculations. Both climate and maize yields were analyzed for each grid cell, and the corresponding dominant soil types were derived from soil texture maps (Hengl et al. 2015). Soil textures were subsequently aggregated into generalized default soil types used in the WOrld FOod STudies (WOFOST) crop model, being coarse (EC1), medium (EC2), and medium fine (EC3) textured soils. This soil classification is highly driven by soil hydrological properties controlling crop yield such as hydraulic conductivity, water retention, and workability. Using the USDA classification, sandy soils (with $86-100 \%$ sand) were classified as coarse-textured (EC1) soils. Loamy sands (with $70-86 \%$ sand, $<30 \%$ silt, and $<15 \%$ clay) were classified as medium textured (EC2) soils and sandy loam soils $(50-70 \%$ sand, $<50 \%$ silt, and $<20 \%$ clay) were classified as medium fine (EC3) soils. For visualization, maize crop areas were selected using a spatial overlay with data of the Spatial Production Allocation Model (IFPRI 2019) at a 5 arc-minute resolution. Model results are reprojected using bilinear interpolation for numeric variables and nearest neighbor for categorial ones.

\subsection{Climate projections}

Bias-corrected data from five selected Global Circulation Models (GCMs) in the Inter-Sectoral Impact Model Intercomparison Project (ISIMIP), at a $0.5^{\circ} \times 0.5^{\circ}$ resolution and a daily timestep, were used to gain insights into the past and projected future climate (Hempel et al. 2013). The selected GCMs included GFDL-ESM2M (Dunne et al. 2012; Dunne et al. 2013), HadGEM2-es (Collins et al. 2011), IPSL-CM5A-LR (Dufresne et al. 2013), MIROC-ESMCHEM (Watanabe et al. 2011), and NorESM-M (Bentsen et al. 2013). Two RCPs were explored, i.e., RCP 4.5 (moderate climate change) and RCP 8.5 (severe climate change) (van Vuuren and Carter 2014). In each RCP, the ensemble average from the GCMs was analyzed for temperature and precipitation indices using Climate Data Operators (Schulzweida 2018). The indices analyzed included average surface temperature, summer days ${ }^{1}$, precipitation, and wet days ${ }^{2}$. To analyze the change in an index, the difference was calculated between the reference period and a future time period.

\subsection{Maize yield modeling}

\subsubsection{Maize yield analysis}

The impact of climate change, current conventional, and optimized management on maize yields was evaluated. To understand the impact of changes in temperature, maize potential production (Yp) was simulated assuming that water and nutrients were not limiting (de Wit et al. 2019; Van Diepen et al., 1989). In addition, to analyze the impact of changes in precipitation, we simulated water-limited rainfed maize production while assuming that nutrients are not limiting. Lastly, to gain insights into the effects of current management on maize yields, the water- and nitrogen-limited maize yields were simulated. We focused on $\mathrm{N}$ limitation as a proxy for nutrient management. We additionally explored the impact of optimized management (varieties and planting dates) on Yw using 77 combinations of varieties and planting dates (Table 1). The optimal combination of variety and planting date

\footnotetext{
${ }^{1}$ Number of days where maximum of temperature is above a specified threshold in degree Celsius. In this study, our threshold were $30{ }^{\circ} \mathrm{C}$ and $35^{\circ} \mathrm{C}$.

${ }^{2}$ Number of days per time period with daily precipitation of at least $1 \mathrm{~mm}$.
} 
was identified by the highest mean yield, the lowest standard deviation, and the highest lower $\left(25^{\text {th }}\right)$ quartile.

\subsubsection{WOFOST model}

The WOFOST model (de Wit et al. 2020) was used to simulate maize production, being a well-known model that has been used in Zambia (Wolf et al. 1987) as well as in regional and global studies (e.g., (Chen et al. 2020; Droppers et al. 2021; Wolf et al. 2015)) including the derivation of the Global Yield Gap Atlas. Crop growth and production were simulated on a daily timestep as determined by crop type, soil type, hydrologic conditions, and weather (Van Diepen et al., 1989). Main processes in the model include phenological development, leaf development, and light interception, $\mathrm{CO}_{2}$ assimilation, root growth, transpiration, respiration, partitioning of assimilates to various storage organs, and dry matter formation (de Wit et al. 2019; Van Diepen et al., 1989). Nutrient dynamics are implemented based on the methods described in (Shibu et al. 2010), while the influence of $\mathrm{CO}_{2}$ on crop growth is described in (Supit et al. 2012). Processes controlling water requirements, consumption, and deficits are described in (Supit et al. 2010). Impacts of heat stress (high temperatures) are included by (i) an increased water requirement, thus increasing water stress, and (ii) a temperature-dependent reduction of assimilation rates. The optimal temperature range for maize growth is between 20 and $30{ }^{\circ} \mathrm{C}$ where the assimilation rate is at maximum. The assimilation rate slowly decreases by $5 \%$ when the temperature increases up to $36^{\circ} \mathrm{C}$, after which is further decreases down to $44 \%$ of the maximum at a temperature of $42{ }^{\circ} \mathrm{C}$. At higher temperatures, the assimilation rate continues to decrease and stops around $52{ }^{\circ} \mathrm{C}$. Details are given in the WOFOST manual (de Wit et al. 2020).

\subsubsection{Model parameterization}

WOFOST was run with daily values of radiation, minimum and maximum temperature, early morning vapor pressure, wind speed and precipitation obtained from the GCMs. Information on soil water retention and hydraulic conductivity as a function of soil moisture tension were based on default values for each soil type (Van Diepen et al., 1989). In the water- and nutrientlimited simulation, we applied $112 \mathrm{~kg} / \mathrm{ha}$ of $\mathrm{N}$ which is the blanket $\mathrm{N}$ recommendation rate in Zambia (Xu et al. 2009), while ensuring that phosphorus and potassium are sufficiently available at planting. The Nitrogen Use Efficiency (NUE), defined as the total $\mathrm{N}$ uptake divided by the total $\mathrm{N}$ input, was set at $50 \%$ based on the global estimate of $47 \%$ (Lassaletta et al. 2014) since actual estimates for Zambia are lacking. Though some studies showed NUE values for SSA above 100\% (Edmonds et al. 2009; Pasley et al. 2020) representing a mining situation, we focused on long-term sustainable maize production and selected a reasonable NUE value of $50 \%$ for African croplands (Bouwman et al. 2013).

We used the standard crop parameter sets of WOFOST, originally compiled by van Heemst (1988) and Boons-Prins et al. (1993), and since then regularly updated with field experimental data. In this study, we used the calibrated crop parameters for maize in SSA from Wolf et al. (2015). A standard tropical maize variety (maiz.w41) was modified by successively adjusting the Temperature sums (Tsum1 and Tsum2) in intervals of 100 degrees, resulting in multiple maize varieties (Table 1). Tsum1 controls the degree days for the period between emergence and anthesis while Tsum2 determines the degree days between anthesis and maturity. Variation in Tsum was derived from experimental data of maize varieties in Zambia where silking 
Table 1 Details on varieties 1-11 (left column) and planting date 1-7 (right column) used in the optimization simulation. Tsum 1 is calculated for the degree days in the period between emergence and anthesis, while Tsum 2 refers to the period between anthesis and maturity

\begin{tabular}{cllcl}
\hline Variety & Tsum1 & Tsum2 & Planting date & Planting date \\
\hline 1 & 685 & 786 & 1 & 28th October \\
2 & 732 & 839 & 2 & 7th November \\
3 & 779 & 892 & 3 & 17th November \\
4 & 825 & 946 & 4 & 27th November \\
5 & 872 & 999 & 5 & 7th December \\
6 & 918 & 1053 & 6 & 17th December \\
7 & 965 & 1106 & 7 & \\
8 & 1012 & 1159 & & \\
9 & 1058 & 1213 & & \\
10 & 1105 & 1266 & & \\
11 & 1151 & 1320 & & \\
\hline
\end{tabular}

occurred around 54-73 days after planting. Maize planting dates in Zambia currently fall between $20^{\text {th }}$ November and 5 December (Chikowo 2016), where we explore planting dates between $28^{\text {th }}$ October and $27^{\text {th }}$ December (Table 1). To gain insights into the effect of management on crop yields, we compared two types of management approaches:

(a) Conventional management, characterized by a fixed planting date ( $26^{\text {th }}$ November) and a common average-performing maize variety $($ Tsum $=1671)$ over the whole country.

(b) Optimized management, characterized by all combinations of 11 varieties and 7 planting dates over the country (where the best option is selected for each grid cell).

\section{Results}

\subsection{Climate indicators}

\subsubsection{Temperature}

Given climate change, the temperature is likely to increase by approximately $2{ }^{\circ} \mathrm{C}$ in both the near and far future. This increase in temperature is coupled with an increase in summer days (Table 2 and Fig. 1), and both factors substantially affected maize growth and yield. When both future climate scenarios are compared, it is evident that the magnitude of temperature changes increased over time. The magnitude of increase was stronger in the far future and in the severe climate change scenario (RCP8.5). The spatial distribution of the expected changes was similar in both RCP scenarios. The increase in summer days (days above $30{ }^{\circ} \mathrm{C}$ ) was stronger in the southern and western parts of the country (Fig. 1). Compared to the reference period, the near future scenarios were projected to have up to 60 more summer days and up to 140 days in the far future. In addition, the number of summer days above $35^{\circ} \mathrm{C}$ increases up to 10 days in the near future and up to 30 days in the far future. The average surface temperature increased on an east-west gradient, with an increase up to $2.6{ }^{\circ} \mathrm{C}$ in the near future and up to $4.6{ }^{\circ} \mathrm{C}$ in 


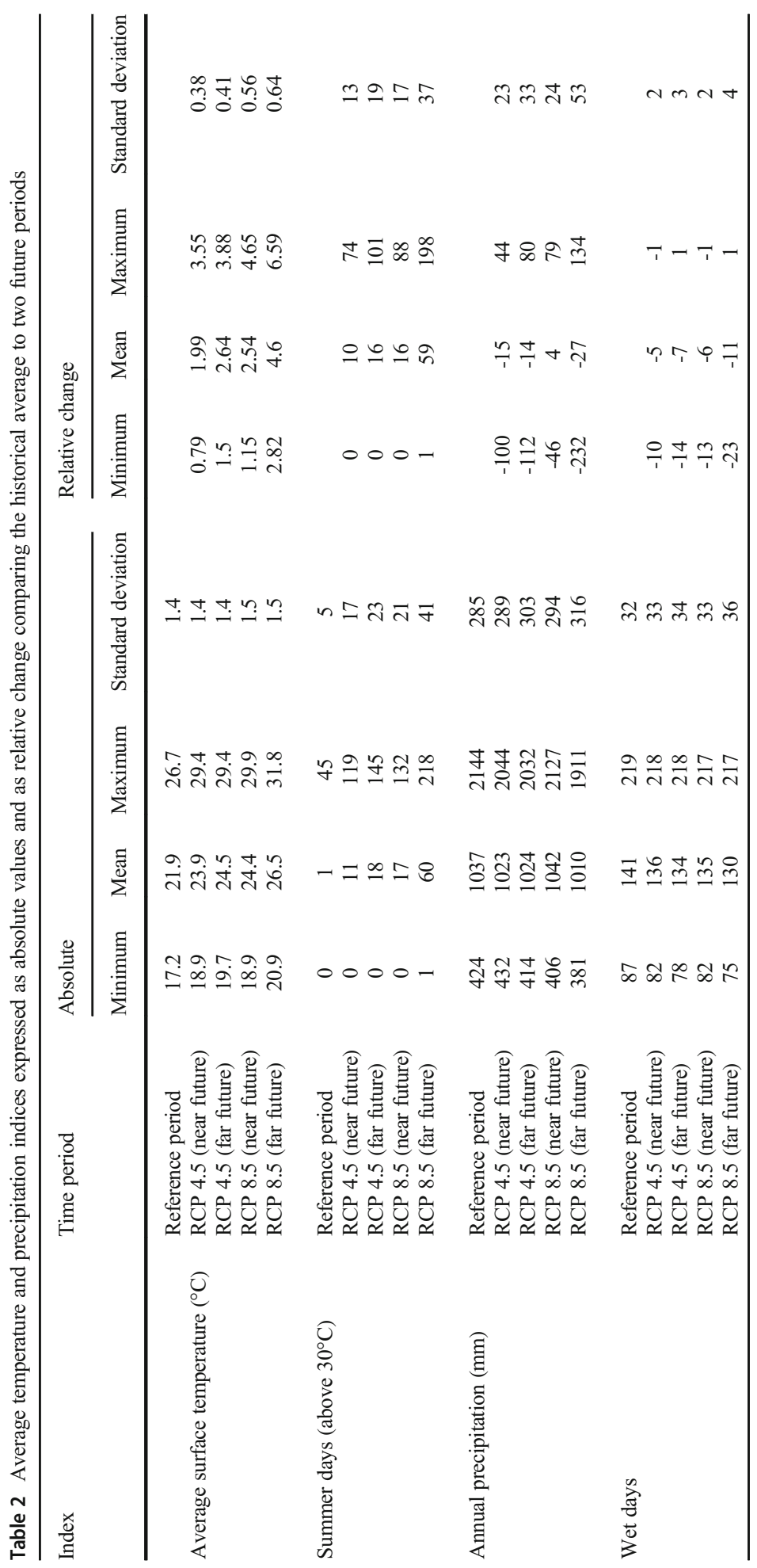



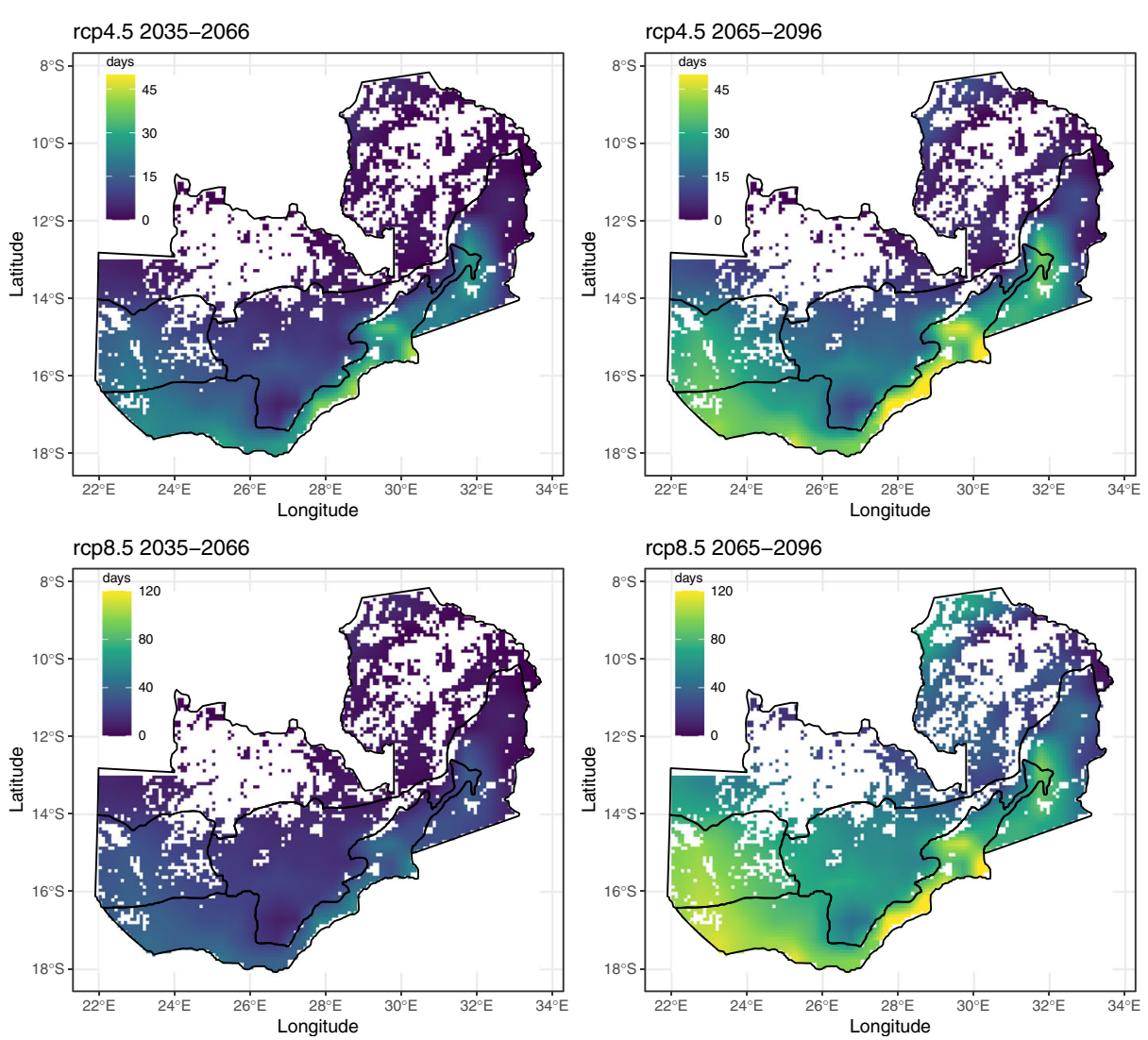

Fig. 1 Projected spatial variation in the relative change in summer days (above $30{ }^{\circ} \mathrm{C}$ ) in $2035-2066$ and 2065 2096 under climate scenarios RCP 4.5 and RCP 8.5 as compared to the reference period (1971-2001)

the far future. During the maize growing season, the projected temperature increased in the October-December period for RCP 4.5 and 8.5 is $2{ }^{\circ} \mathrm{C}$ and $3{ }^{\circ} \mathrm{C}$ (near future) and 3 ${ }^{\circ} \mathrm{C}$ and $5{ }^{\circ} \mathrm{C}$ (far future). Further projections for the period January-March, the temperature increased by $1.6{ }^{\circ} \mathrm{C}$ and $2.2{ }^{\circ} \mathrm{C}$ (near future) and $2.2{ }^{\circ} \mathrm{C}$ and $4{ }^{\circ} \mathrm{C}$ (far future) for RCP 4.5 and RCP 8.5 respectively

\subsubsection{Precipitation}

Over the whole country, the number of wet days was likely to decline (Table 2). In the near future, the number will reduce by 5 and 6 days, while in the far, future it decreases by 7 and 11 days for RCP 4.5 and RCP 8.5 respectively. The reduction in wet days was stronger towards the south-west regions. On average, both RCP scenarios showed a general reduction in the annual precipitation, but it increased in the northern and decreased in the southern-western regions (Fig. 2 and Table 2). In future projections, there was a reduction of precipitation in the onset of rain season and increase towards end of the season (Data not shown here). 


\subsection{Maize yields}

\subsubsection{Spatial variation in potential, water-limited, and water- and nutrient-limited yields in the reference period}

In the reference period, the potential yields (Yp) ranged from 5.3 to 15.3 tons/ha with a mean of $9.9 \pm 1.4$ tons/ha, whereas the water-limited yields (Yw) ranged from 4.0 to 15.0 tons/ha with a mean of $9.5 \pm 1.6$ tons/ha (Fig. 3). The averaged Yw was slightly lower than predictions given in Global Yield Gap Atlas (GYGA), which is on average 11.3 tons/ha. The water- and nutrient-limited yield (Yn) ranged from 2.4 to 5.6 tons/ha with an average yield of $4.7 \pm 0.7$ tons/ha. The difference between $\mathrm{Yw}$ and $\mathrm{Yn}$ was 4.8 tons $/ \mathrm{ha}$. Currently, the lowest yields were found in the western and southern parts of the country, being part of agroecological region I (Fig. 3). The Yn was almost 2 ton/ha higher than the average actual yield (Ya), which varied between 2 and 3 ton/ha (www.yieldgap.org accessed on: 23/03/2020).
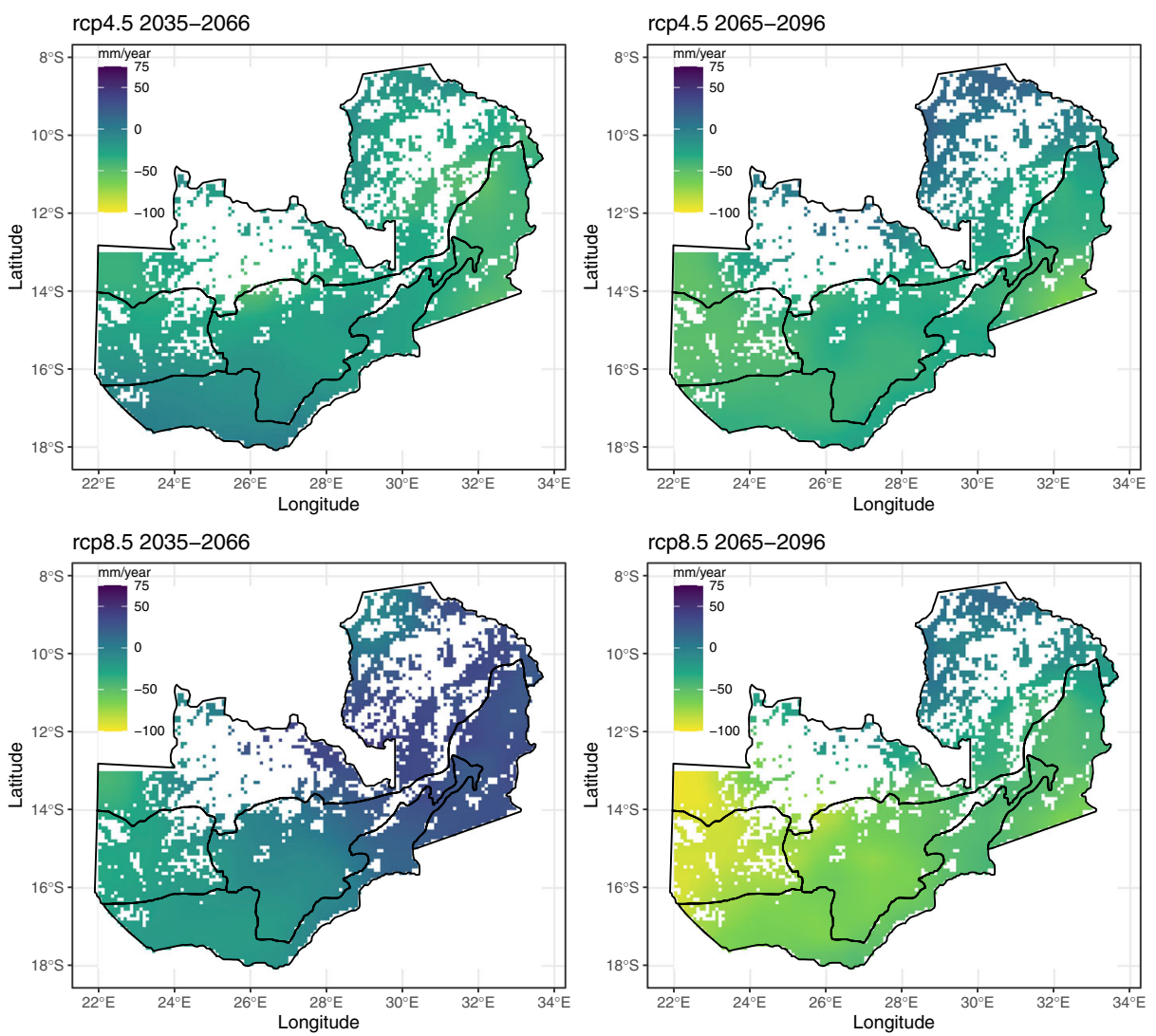

Fig. 2 Projected spatial variation in the relative change in average annual precipitation (mm-yr-1) in 2035-2066 and 2065-2096 under climate scenarios RCP 4.5 and RCP 8.5 as compared to the reference period (1971-2001) 

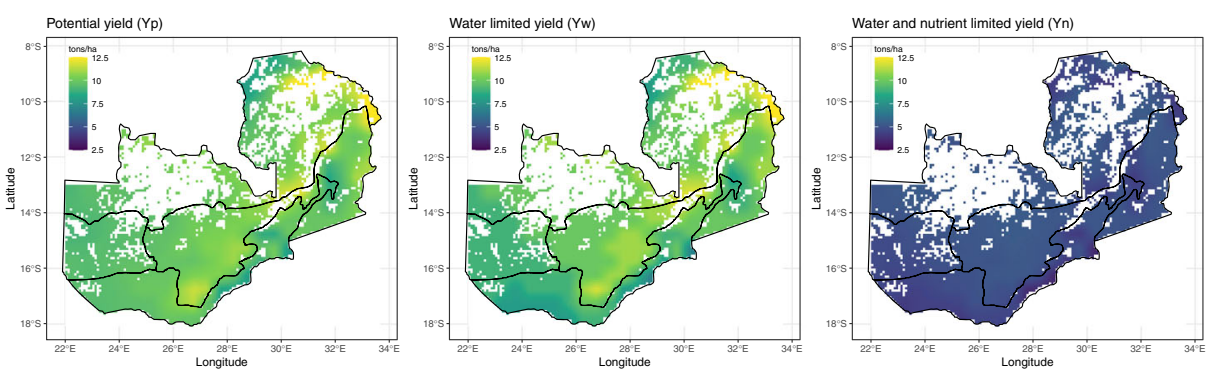

Fig. 3 Simulated spatial variation in potential yields (Yp), water-limited yields (Yw), and water- and nutrientlimited yield (Yn) during the reference period (1971-2001)

\subsubsection{Relative changes in maize yields due to temperature and precipitation changes}

Table 3 shows that in the near future, the Yp declined due to increased temperature in both RCP 4.5 and 8.5. Yield declined with 1.4 to 2.0 tons/ha, being equal to a decline of $15 \%$ to $21 \%$ compared to the Yp in the reference period. In the far future, a country average reduction of 1.9 ton/ha (20\%) for RCP 4.5 and 3.5 tons/ha (36\%) for RCP 8.5 is expected. For both RCPs, the decline in Yw equaled the decline in Yp for both the near and far future, indicating that the change in temperature had a stronger impact on $\mathrm{Yw}$ than the change in precipitation. Similarly, the relative changes in Yn and Yw were comparable (Table 3).

\subsubsection{Mitigating negative impacts of climate change by optimal crop management}

Figure 4 gives projections of Yw maize yields under "conventional management," consisting of a fixed planting date and variety (left) against "optimized management" consisting of optimized planting dates and varieties (right). Optimal management had a positive impact on maize yields under climate change. With conventional management in RCP 4.5, maize yield declined down to 1.4 ton/ha $(15 \%)$ in the near future and down to 1.9 ton/ha $(21 \%)$ in the far future. Under optimized management for the same RCP scenario, the projected yield declined with 0.8 ton/ha $(8 \%)$ in the near future and with 1.3 ton/ha $(14 \%)$ in the far future (Table 3). Under conventional management in RCP 8.5, a yield decline of 1.9 ton/ha (21\%) in the near future and 3.5 ton/ha (37\%) in the far future was shown for $\mathrm{Yw}$ (Table 3). However, optimizing management for the same RCP scenario, we generally have a yield decline of 1.4 ton/ha $(15 \%)$ in the near future and 2.9 tons/ha $(31 \%)$ in the far future.

The relative changes in Yn due to climate change were comparable to Yw. Under conventional management, the average yield declined in the near future by 0.7 tons/ha (16\%) in RCP 4.5 and 1.0 tons/ha (22\%) in RCP 8.5. For the far future, the yield declined with 1.1 tons/ha $(22 \%)$ and 2.0 tons/ha (41\%) respectively. However, optimizing management mitigated the decline in Yn by increasing yields except for the RCP 8.5 scenario in the far future (Table 3). For instance, there was an increase of 0.2 tons/ha (6\%) for RCP 4.5 and 0.02 tons/ha (2\%) for RCP 8.5 in the near future. In the far future, optimizing management increased $\mathrm{Yn}$ in RCP 4.5 by 0.1 tons/ha $(3 \%)$ whereas in RCP 8.5 the yield decreased by 0.6 tons/ha (12\%) (Table 3). The difference between the relative yield change under conventional and optimized management showed that management measures could avoid the climate-induced yield decline by 6-29\% for both $\mathrm{Yw}$ and Yn. 
Table 3 Summary statistics on the expected absolute and relative changes in maize yield change in the near future (2035-2066) and far future (2065-2096) compared to the reference period (1971-2001) at country level

\begin{tabular}{|c|c|c|c|c|c|c|}
\hline Index & RCP & $\begin{array}{l}\text { Mean } \\
\text { tons } \cdot h \text { ? }\end{array}$ & $\begin{array}{l}\text { Standard } \\
\text { deviation }\end{array}$ & Minimum & Maximum & $\begin{array}{l}\text { Relative } \\
\text { mean }\end{array}$ \\
\hline \multirow[t]{4}{*}{ Potential yield } & $\begin{array}{c}\text { RCP } 4.5 \\
\text { (near } \\
\text { future) }\end{array}$ & -1.4 & 0.23 & -1 & -2.3 & $-15 \%$ \\
\hline & $\begin{array}{l}\mathrm{RCP} 4.5 \text { (far } \\
\quad \text { future) }\end{array}$ & -1.9 & 0.23 & -1.5 & -3 & $-20 \%$ \\
\hline & $\begin{array}{l}\text { RCP } 8.5 \\
\quad \text { (near } \\
\text { future) }\end{array}$ & -2.0 & 0.29 & -1.4 & -3.2 & $-21 \%$ \\
\hline & $\begin{array}{l}\text { RCP } 8.5 \text { (far } \\
\text { future) }\end{array}$ & -3.5 & 0.34 & -2.6 & -5 & $-36 \%$ \\
\hline \multirow[t]{4}{*}{$\begin{array}{l}\text { Water limited (current conventional } \\
\text { management) }\end{array}$} & $\begin{array}{l}\text { RCP } 4.5 \\
\text { (near } \\
\text { future) }\end{array}$ & -1.4 & 0.29 & -0.3 & -2.3 & $-15 \%$ \\
\hline & $\begin{array}{l}\mathrm{RCP} 4.5 \text { (far } \\
\quad \text { future) }\end{array}$ & -1.9 & 0.27 & -0.9 & -3 & $-21 \%$ \\
\hline & $\begin{array}{l}\text { RCP } 8.5 \\
\quad \text { (near } \\
\text { future) }\end{array}$ & -1.9 & 0.39 & -0.5 & -3.2 & $-21 \%$ \\
\hline & $\begin{array}{l}\text { RCP } 8.5 \text { (far } \\
\text { future) }\end{array}$ & -3.5 & 0.37 & -1.9 & -5 & $-37 \%$ \\
\hline \multirow[t]{4}{*}{$\begin{array}{l}\text { Water limited (optimized } \\
\text { management) }\end{array}$} & $\begin{array}{l}\text { RCP } 4.5 \\
\text { (near } \\
\text { future) }\end{array}$ & -0.8 & 0.28 & -1.5 & 0.3 & $-8 \%$ \\
\hline & $\begin{array}{l}\mathrm{RCP} 4.5 \text { (far } \\
\quad \text { future) }\end{array}$ & -1.3 & 0.28 & -0.1 & -2.2 & $-14 \%$ \\
\hline & $\begin{array}{l}\text { RCP } 8.5 \\
\text { (near } \\
\text { future) }\end{array}$ & -1.4 & 0.24 & -1.9 & -2.2 & $-15 \%$ \\
\hline & $\begin{array}{l}\text { RCP } 8.5 \text { (far } \\
\text { future) }\end{array}$ & -2.9 & 0.32 & -0.9 & -4.2 & $-31 \%$ \\
\hline \multirow[t]{4}{*}{$\begin{array}{l}\text { Water and Nitrogen limited (current } \\
\text { conventional management) }\end{array}$} & $\begin{array}{l}\text { RCP } 4.5 \\
\quad \text { (near } \\
\text { future) }\end{array}$ & -0.7 & 0.59 & -1.4 & 1.4 & $-16 \%$ \\
\hline & $\begin{array}{l}\mathrm{RCP} 4.5 \text { (far } \\
\quad \text { future) }\end{array}$ & -1.1 & 0.67 & -1.7 & 1.6 & $-22 \%$ \\
\hline & $\begin{array}{c}\text { RCP } 8.5 \\
\text { (near } \\
\text { future) }\end{array}$ & -1 & 0.65 & -1.9 & 1.5 & $-22 \%$ \\
\hline & $\begin{array}{l}\mathrm{RCP} 8.5 \text { (far } \\
\quad \text { future) }\end{array}$ & -2 & 0.68 & -2.8 & 2 & $-41 \%$ \\
\hline \multirow[t]{4}{*}{$\begin{array}{l}\text { Water and Nitrogen limited } \\
\text { (Optimized management) }\end{array}$} & $\begin{array}{l}\mathrm{RCP} 4.5 \\
\quad \text { (near } \\
\text { future) }\end{array}$ & 0.2 & 0.46 & -0.3 & 2.4 & $6 \%$ \\
\hline & $\begin{array}{l}\mathrm{RCP} 4.5 \text { (far } \\
\quad \text { future) }\end{array}$ & 0.1 & 0.46 & -0.5 & 2.5 & $3 \%$ \\
\hline & $\begin{array}{l}\text { RCP } 8.5 \\
\text { (near } \\
\text { future) }\end{array}$ & 0.02 & 0.44 & -0.5 & 2.4 & $2 \%$ \\
\hline & $\begin{array}{l}\mathrm{RCP} 8.5 \text { (far } \\
\quad \text { future) }\end{array}$ & -0.6 & 0.5 & -1.2 & 2.1 & $-12 \%$ \\
\hline
\end{tabular}



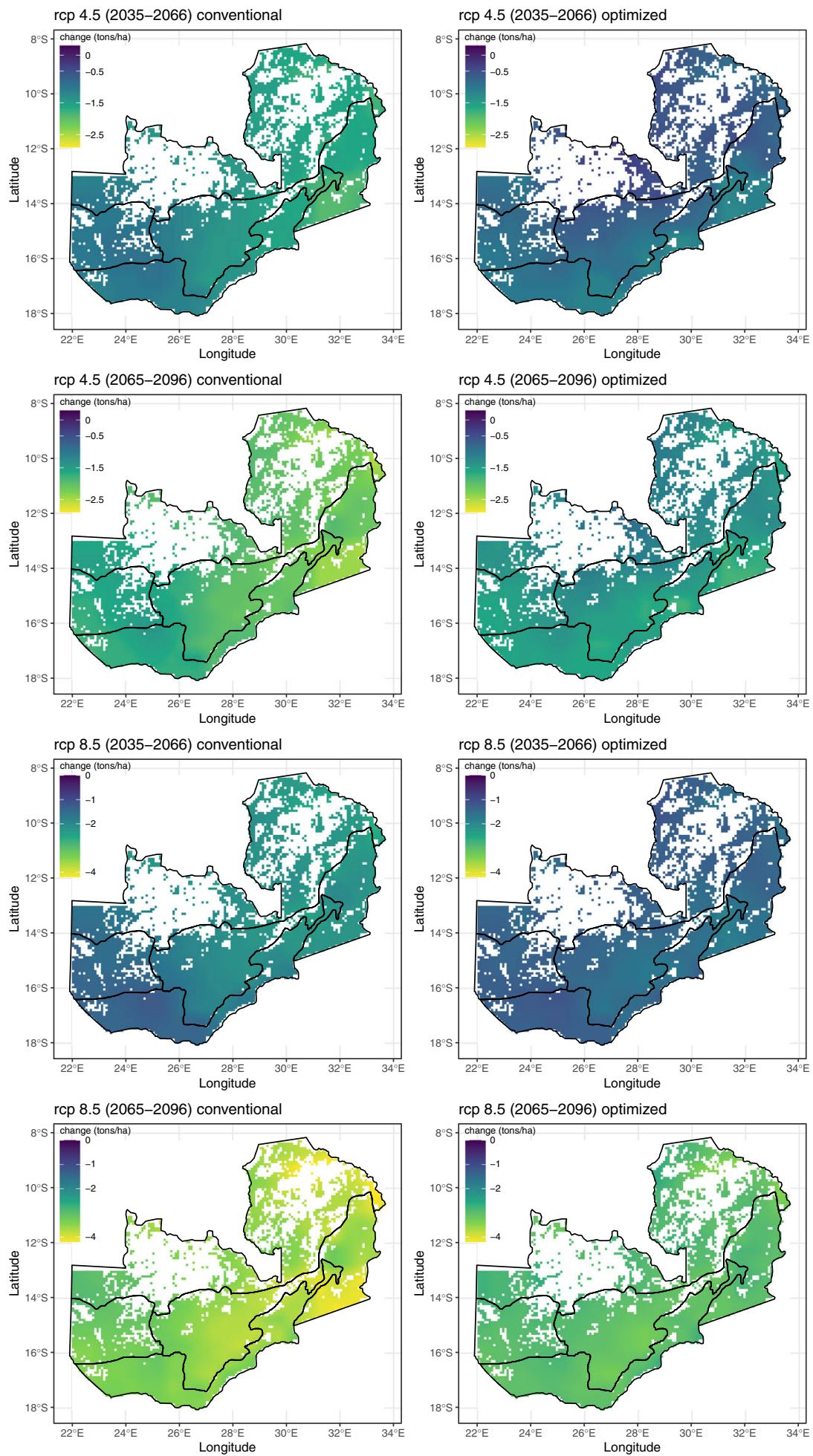
Fig. 4 Predicted spatial variation in the changes in water-limited maize yields in 2035-2066 and 2065-2096 under climate scenarios RCP 4.5 and RCP 8.5 under conventional management (left column) and under optimized management (right column)

Figure 5 shows that the best variety option for the western and southern region includes the use of relatively early maturing varieties (90-120 days) or those varieties with Tsum values slightly above average (variety 3 in Table 1). In these regions, the optimal variety had Tsum values ranging between 1471 and 1871 (Variety 1-5), while the rest of the country was best suited with a variety that has a Tsum around 2071 (Variety 7). Figure 6 shows the suitable planting date for each region in the near and far future for both RCP 4.5 and 8.5. Suitable planting dates ranged from late November to mid-December except for the RCP 8.5 scenario in the far future. For the southern and western regions, suitable planting dates started around $27^{\text {th }}$ November, while the maize in the other regions should be planted between $7^{\text {th }}$ and $17^{\text {th }}$ December. Combining Figs. 5 and 6 shows that the western and southern regions were best suited for early maturing varieties planted early in the suitable growing season. The rest of the country, particularly in the northern region, was best suited for late-maturing varieties.
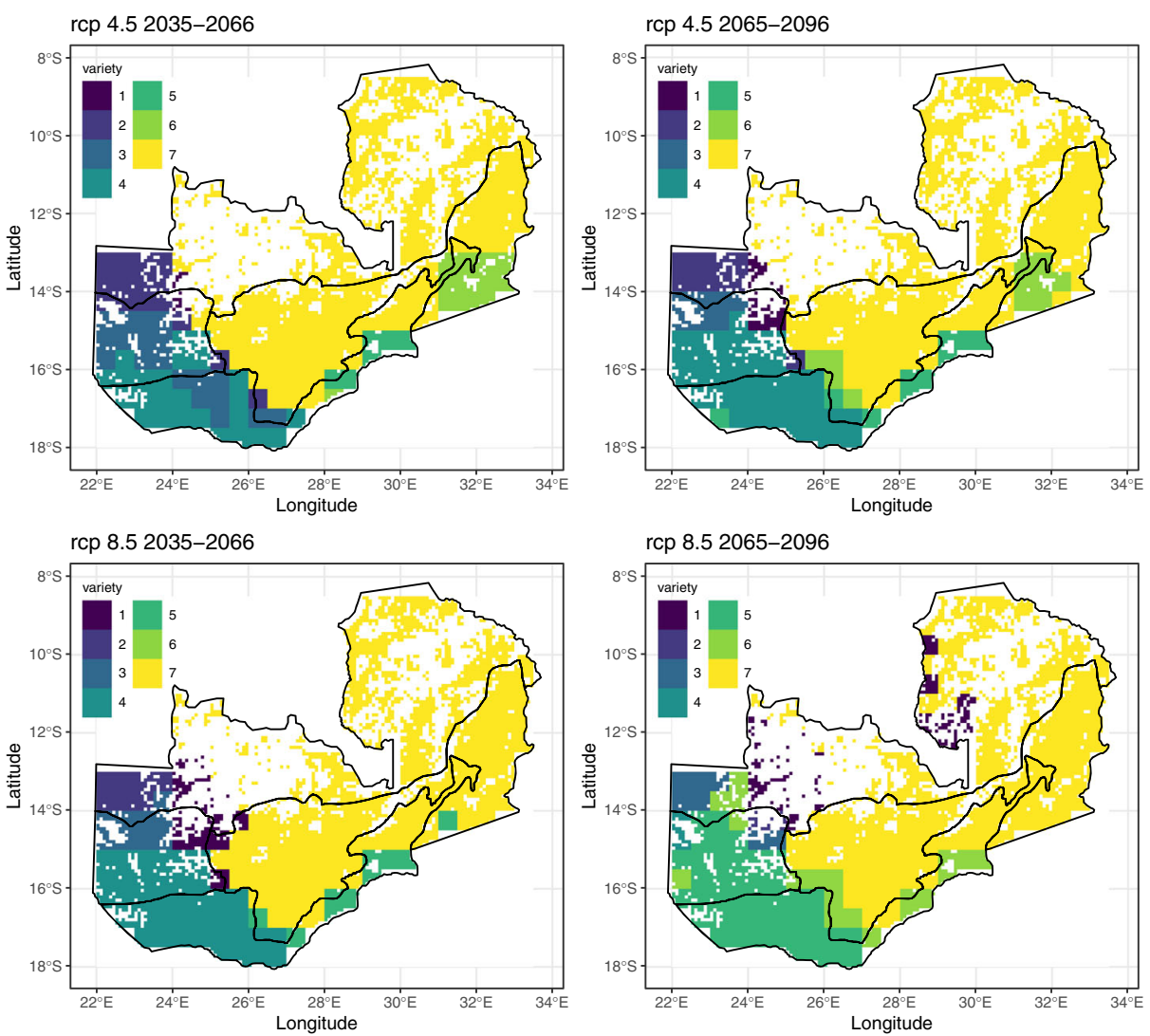

Fig. 5 Predicted spatial variation in the best-suited maize variety (see Table 1) in 2035-2066 and 2065-2096 under climate scenarios RCP 4.5 and RCP 8.5 

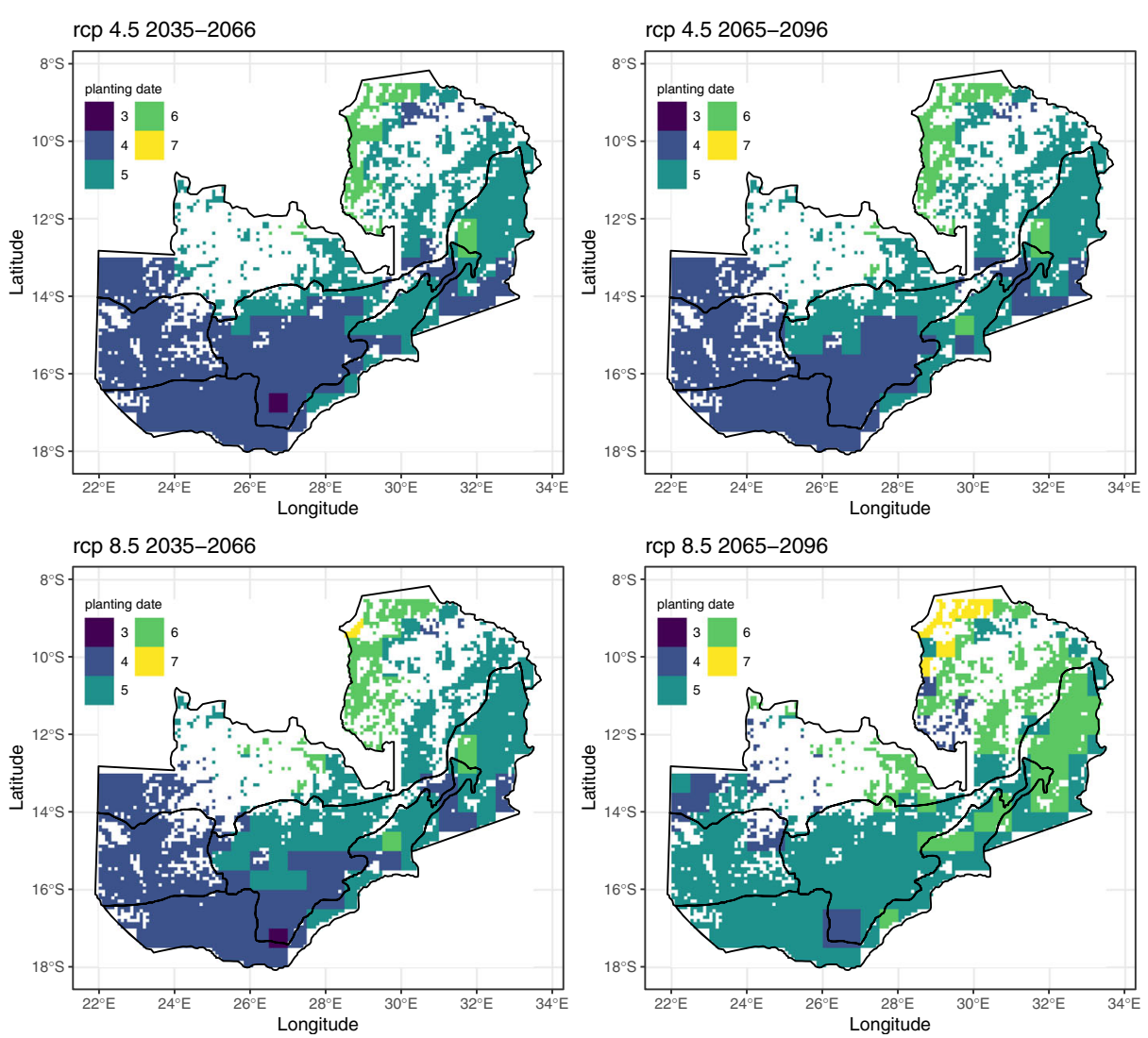

Fig. 6 Predicted spatial variation in the best-suited maize planting date (see Table 1) in 2035-2066 and 20652096 under climate scenarios RCP 4.5 and RCP 8.5

\section{Discussion}

\subsection{Expected precipitation and temperature changes and its implications}

Zambia's climate is projected to change mainly by a decrease in precipitation and an increase in temperature, especially in the south-western regions. These changes will negatively impact maize yields in both the short and long term. Fortunately, agronomic management such as appropriate nutrients, varieties, and planting dates has the potential to mitigate some of these negative impacts, and they can even reduce substantial parts of the existing yield gap. Translating this knowledge in manageable actions requires an agroecological approach accounting for location-specific farm and field properties.

Climate change will increase the number of days with temperatures above $30^{\circ} \mathrm{C}$ and reduce the number of cooler days. This is consistent with findings at a global level (IPCC 2014) as well for southern Africa (Kruger and Shongwe 2004; New et al. 2006). Nevertheless, the spatial variation is huge with strong spatial patterns around the borders with Namibia, Botswana, Zimbabwe, and Mozambique (Fig. 1) due to the lower attitude and adiabatic descent leading to higher temperatures than the surrounding regions (New et al. 2006). Areas with high risks for heat-related stresses are likely to occur in Agroecological region I. 
In addition, the annual average surface temperatures are also expected to increase, similar to the projected global trends (IPCC 2013; Lobell et al. 2011b) as well as regional trends in southern Africa (Maúre et al. 2018; New et al. 2006). However, the magnitude of change in Zambia is expected to be larger than the global average (Engelbrecht et al. 2015; IPCC 2014; Nikulin et al. 2018), a difference that can increase up to a factor of ten as shown by (Jain 2007) based on observations from 32 thirty-two meteorological stations over thirty years. A temperature increase will enhance potential evapotranspiration and corresponding crop water demand (Brüssow et al. 2019; Parent and Tardieu 2012), in particular for situations with water deficiencies (Déqué et al. 2017). Temperature changes are projected to be stronger westwards due to warming in the Indian ocean (Engelbrecht et al. 2015; Maúre et al. 2018).

Precipitation will decline in most of the regions except for the northern and north-western regions where convective precipitation increases due to changes in the synoptic-scale circulations for the eastern regions of southern Africa (Engelbrecht et al. 2009; Fauchereau et al. 2003; Pinto et al. 2016). Southern and western regions will be drier due to a reduction in both annual precipitation and wet days. Both drought and warmer temperatures increase the vulnerability of maize due to dry spells and heat stresses. The least relative change in wet days coupled with an increase in annual precipitation is expected in the northern region (AEZ III) implying an increase in occurrences of heavy precipitation events thus posing the risk of flooding or crop damage due to logging (Déqué et al. 2017). The overall reduction in the number of wet days is in line with earlier findings implying a shortening growing season, increased threat of crop failure, and livelihoods of smallholder farmers (Makondo and Thomas 2020; New et al. 2006). The reduction in rainfall might be small in magnitude, but generally, this has been consistent with multiple findings (Jain 2007; Maúre et al. 2018; New et al. 2006; Pinto et al. 2016). Such an occurrence increases the risk of crop failure due to either lack or too much water in the south-western and north-western regions respectively.

\subsection{Expected climate change impacts on maize yield}

The simulated rainfed (Yw) maize yield is $9.5 \pm 1.6$ tons $\cdot$ ha $^{-1}$ which is in the same order of magnitude as those presented in the Global Yield Gap and Water Productivity Atlas. This yield estimate is based on good agronomic management comprised of suitable varieties and planting dates and appropriate fertilization, pest, and disease control. However, in reality, the actual yields are about $80 \%$ lower due to conventional management limitations. Commonly, smallholder farmers use subjective estimations to select the planting date and maize varieties based on perceived rain patterns or growing season (Brüssow et al. 2019) and blanket fertilization strategies (Njoroge et al. 2017; Xu et al. 2009). As a consequence, actual yields (2-3 tons/ha) are significantly lower than the potentially achievable rainfed yield.

Maize yields may decline due to climatic-induced changes in temperature and rainfall. Higher $\mathrm{CO}_{2}$ levels are not expected to have much of an influence on maize given its a $\mathrm{C} 4$ plant type (Leakey 2009). The decline in yield is therefore largely controlled by the change in temperature. The projected yield reduction trend is aligned with the projected global trends and other regional studies (Lobell and Field 2007; Zinyengere et al. 2013), and strongly determined by the daily maximum temperature given its influence on the phenological development of the maize. Higher temperatures reduce the time for photosynthesis and grain filling which in turn reduces yield (Craufurd and Wheeler 2009; Liu et al. 2013; Liu et al. 2012). During the growing season, temperatures in the far future could increase from the reference temperature of $24{ }^{\circ} \mathrm{C}$ by up to 3 to $5{ }^{\circ} \mathrm{C}$ for RCP 4.5 and RCP 8.5 respectively. 
There are various suggested thresholds beyond which maize yield decline, varying from 29 ${ }^{\circ} \mathrm{C}$ (Schlenker and Roberts 2009), $30{ }^{\circ} \mathrm{C}$ (Lobell et al. 2011a), $36{ }^{\circ} \mathrm{C}$ (Sánchez et al. 2014), and even $40^{\circ} \mathrm{C}$ (Birch et al. 1998). With the expected increase in the number of hot days (with temperatures above $30^{\circ} \mathrm{C}$ ), it is clear that the potential yields decline, in particular when the temperature exceeds the $36^{\circ} \mathrm{C}$. The expected yield decline is relatively largest in high-yielding areas (Schlenker and Lobell 2010). The projected increase in temperature had a relatively stronger contribution for the decrease in maize yields than changes in rainfall. Since the annual rainfall exceeds $700 \mathrm{~mm}$ in most of Zambia, the projected precipitation decrease has only a slight impact on crop production (Liu et al. 2012). Knowing that future rainfall shows high spatial and temporal variability, especially in the semi-arid regions, maize yield might show more drastic negative effects than those derived from temperature changes only.

Maize Yw growing under conventional management indicates that yield reduction takes an eastward trend similar to Yp. This trend of yield change coupled with the precipitation analyses indicates that most of the future maize yield reduction in Zambia can be largely attributed to a change in temperature. This increase in temperature would also increase water demand by crops (Brüssow et al. 2019). Hence, the threat of crop failure increases especially when the increase in temperature is not compensated with an increase in precipitation (Déqué et al. 2017). The importance of temperature for crop yield is supported by previous studies showing that temperature has a stronger influence on yields than precipitation (Lobell and Field 2007; Schlenker and Lobell 2010). These findings indicate that adaptation activities should include significant efforts to breed maize varieties that are heat and drought tolerant due to expected increases in temperature and changes in rainfall.

There is a difference of approximately 5 tons/ha between Yn and Yw, indicating that current yields are limited by nutrient availability. Other studies have indeed emphasized that nutrient management will complement adaptation efforts (Schlenker and Lobell 2010). Yn will decline by 16-41\% compared to $15-36 \%$ reduction expected for Yp and Yw. The slightly higher reduction in $\mathrm{Yn}$ is due to a climate-induced reduction in NUE given that more rainfall and higher temperatures enhance risks for $\mathrm{N}$ losses via volatilization and leaching (Falconnier et al. 2020). Furthermore, water deficits coupled with increased temperatures lead to lower nitrogen uptake and crop yield (Liang et al. 2018). Optimizing management practices including fertilizer application has the potential to mitigate the impacts of climate change on maize yields. For instance, split fertilizer application and manure application can improve both NUE and yields (Falconnier et al. 2020; Liang et al. 2018). Even though the absolute magnitude of Yn, Yw, and Yp may be highly uncertain at local scale, the simulated relative changes in crop yield potentials due to climate change as well as the impact of mitigation measures are still valid (Zinyengere et al. 2013).

\subsection{Uncertainty in predicted climate change impacts}

Like any crop model, WOFOST embodies various assumptions and simplifications, such as the absence of processes quantifying the ability of plants to adapt to low resource conditions by modifying its morphology and physiology. WOFOST may therefore overestimate the drought effects. Sowing date variations or occurrence of re-sowing in response to droughts may occur at a regional scale. However, since no information on these phenomena is available, an average sowing date per grid box is assumed. In addition, the projected magnitudes of changes in climatic variables are subject to uncertainties arising from the standard structure of GCMs, climate change scenarios, and initial conditions (Woldemeskel et al. 2014). Therefore, to 
reduce these uncertainties, we used five GCMs ensemble averages to quantify the changes (Dale et al. 2017).

Furthermore, the accuracy of predicted changes in water-limited crop yields in response to climate change, especially an increasing temperature, depends mainly on the accuracy in which crop growth models include the interacting effects of drought, rising temperatures, and $\mathrm{CO}_{2}$ fertilization. This refers to the description of the yield-enhancing effects of $\mathrm{CO}_{2}$ fertilization that may dampen the negative impacts of rising temperatures and drought or the way in which water availability dampens the effect of high temperatures. Insight in the accuracy has to come from experimental field evidence as highlighted by Silva and Giller (2021). They illustrate this point for coffee, where research under controlled conditions suggests impacts at temperatures above $33{ }^{\circ} \mathrm{C}$, whereas high yields are observed in irrigated areas where maximum temperatures exceeding $35^{\circ} \mathrm{C}$ up to $39^{\circ} \mathrm{C}$. Fortunately, cereals, including maize, are much more intensively researched than other crops, and hence, the experimental evidence underpinning the model parameterization for maize in WOFOST is quite high. Nevertheless, uncertainties in interacting effects of water, temperature, and $\mathrm{CO}_{2}$ are still topics of research.

Another uncertainty is related to the aggregation of the variation in management, climate and soil properties by using a 0.5 degrees spatial resolution for modeling, implying that regional variation at higher resolution is not accounted for. This generalization might have implications on the magnitude of change in yields; however, the relative changes across scenarios are unaffected. As a consequence, the current data availability does not yet allow us to predict future conditions at the degree of spatial, temporal, and probabilistic precision which is needed for locally adapted decisions making (Nissan et al. 2019).

\subsection{Potential to reduce climate change impacts by management}

This study focuses on options to increase maize yields by improving management (adapting planting dates and crop varieties) that mitigate climate change impacts, measures that have also been identified as a promising way to improve wheat yields in Australia (Richards et al. 2014). There is also the option to change the cropping system to other more heat and drought tolerant crops. However, as considering the expected climate change, there is still enough room to improve the maize yield. Furthermore, switching from maize as a staple food to an another may encounter societal difficulties.

Optimizing management by appropriate planting date and variety reduced the magnitude of yield decline for both $\mathrm{Yw}$ and $\mathrm{Yn}$ in the near and far future by ca 6-29\% as compared to conventional management, being comparable to findings in a field survey (Karapinar and Özertan 2020). Maize grain yields have increased by $4 \%$ due to changes in sowing date and $13-38 \%$ due to change in cultivar (Liu et al. 2013) and by $7.1-57.2 \%$ by a change in both sowing data and cultivars during the period 1981-2007 (Zhao et al. 2015) .

The thermal attributes of varieties was the main differences in this context, and it is worth noting that varieties in reality vary on more than thermal attributes. A slightly better improvement was predicted for Yn than for Yw, even causing an increases in yields compared to the reference period, despite climate change. This is probably due to synergistic interactions between the shift in planting dates and the date of fertilization (Johnston and Bruulsema 2014).

Western and southern Zambia are expected to have high temperature increase coupled with less rainfall; this means we need to plant early maturing drought tolerant varieties and select suitable planting dates. Optimizing management is beneficial, cheap, and easy to implement 
since it is incremental adaptation and avoids huge financial investments (Challinor et al. 2014; Karapinar and Özertan 2020; Lobell et al. 2011b). However, adopting these "cheap" technologies will require an enabling environment based on a systems approach to ensure that farmers access the suitable varieties in good time especially for the resource-constrained farmer under the Zambian government input support program (Arslan et al. 2015). Furthermore, adopting these options is subject to a farmer's risk perception of changes in climate; therefore, there is a need for sensitization (Brüssow et al. 2019). Various studies have highlighted the benefits of variety choices and planting dates as adaptation strategies (Araya et al. 2020). However, it is important to note that there exists a time lag between development, dissemination, and acceptance of improved varieties and it is thus important to prioritize research in developing improved varieties (Cairns et al. 2013).

Based on our results, the yield gap between $\mathrm{Yw}$ and $\mathrm{Yn}$ is estimated at 50\%, being on average near 5 tons/ha, while the yield gap atlas calculates the yield gap between $\mathrm{Yw}$ and $\mathrm{Ya}$ at $70-80 \%$ translating to 9-10 tons/ha. The gap between $\mathrm{Yw}$ and $\mathrm{Yn}$ is due to nutrient limitation with $\mathrm{N}$ as a surrogate, while the gap between $\mathrm{Yw}$ and $\mathrm{Ya}$ is due to nutrient limitations, weeds, pests, diseases, and pollutants (Van Ittersum et al. 2013). It is, therefore, important to increase yields, as a first priority before we address climate change adaptation (Crespo et al. 2011). Our findings highlight that nutrient limitation plays a key role in the current yield gaps. This can also be seen from the $\mathrm{N}$ requirements of maize at a target yield of, e.g. 8 tons/ha (Lobell et al. 2009; Sadras et al. 2015). A target yield of 8 tons/ha equals a N fertilizer demand of $240 \mathrm{~kg} \mathrm{~N} /$ ha (assuming a $\mathrm{N}$ content of $1.5 \%$ (Yang et al. 2012) and a NUE of 50\%), resulting in a $\mathrm{N}$ demand exceeding the recommended $\mathrm{N}$ input of $112 \mathrm{~kg} \mathrm{~N} / \mathrm{ha}$. When we aim for a yield of 8 tons/ha, and assume a slightly higher potential NUE of $60 \%$ by proper fertilizer management including appropriate additions of phosphorus and zinc that often limit crop yields in Zambia (Yerokun 2008; Yerokun and Chirwa 2014), an N input of $200 \mathrm{~kg} \mathrm{~N} / \mathrm{ha}$ would be recommended. Conclusively, increasing the actual yields will require a holistic farm system approach considering various aspects of agronomic management including land preparation, pest and disease control, and weed management.

\section{Conclusions}

Climate-induced changes in temperature, precipitation, and corresponding impacts on maize yields in Zambia have been quantified. Results show that without countermeasures, maize yields will decline by $20-40 \%$ in particular for the southern and western regions. Currently, maize yield gaps due to nutrient limitations are projected to widen due to climate change if no counter measures are introduced. Improved agronomic and nutrient management can mitigate the climate-induced negative impacts on crop yield, eventually improving crop yield in all regions across Zambia. A closer look indicates that the change in temperature has a stronger negative impact than the change in precipitation, although this varied across Zambia. The southern and western regions should focus on measures addressing the higher temperature and reduced precipitation whereas the northern region struggles with higher temperature levels as well as high precipitation. Maize varieties that are tolerant for higher temperatures are always beneficial. Fertilizer strategies improving NUE will boost crop production, avoiding some of the negative impact of climate change. More attention to earlier onsets of the rain season might be important for further optimization of maize production. This model study confirms that via 
optimum agronomic management the actual crop yields can be improved substantially, thereby closing the existing yield gap and mitigating negative climate-induced impacts.

Acknowledgments This study was supported by Wageningen University and Research and Mulungushi University.

Funding This work is part of a PhD fellowship funded by Wageningen University and Research in collaboration with Mulungushi University.

Data availability The climate and crop simulation data are readily available on request.

Code availability The custom code of WOFOST in C can be accessed on https://github.com/isupit/wofost_c

\section{Declarations}

Conflict of interest The authors declare that there are no conflicts of interest.

Open Access This article is licensed under a Creative Commons Attribution 4.0 International License, which permits use, sharing, adaptation, distribution and reproduction in any medium or format, as long as you give appropriate credit to the original author(s) and the source, provide a link to the Creative Commons licence, and indicate if changes were made. The images or other third party material in this article are included in the article's Creative Commons licence, unless indicated otherwise in a credit line to the material. If material is not included in the article's Creative Commons licence and your intended use is not permitted by statutory regulation or exceeds the permitted use, you will need to obtain permission directly from the copyright holder. To view a copy of this licence, visit http://creativecommons.org/licenses/by/4.0/.

\section{References}

Araya A, Prasad P, Gowda P, Djanaguiraman M, Kassa A (2020) Potential impacts of climate change factors and agronomic adaptation strategies on wheat yields in central highlands of Ethiopia. Clim Chang:1-19

Arslan A, McCarthy N, Lipper L, Asfaw S, Cattaneo A, Kokwe M (2015) Climate smart agriculture? Assessing the adaptation implications in Zambia. J Agric Econ 66:753-780

Becsi B, Hohenwallner-Ries D, Grothmann T, Prutsch A, Huber T, Formayer H (2020) Towards better informed adaptation strategies: co-designing climate change impact maps for Austrian regions. Clim Chang 158:393411

Bentsen M, Bethke I, Debernard JB, Iversen T, Kirkevåg A, Seland Ø, Drange H, Roelandt C, Seierstad IA, Hoose C (2013) The Norwegian earth system model, NorESM1-M-Part 1: description and basic evaluation of the physical climate. Geosci. Model Dev 6:687-720

Birch C, Rickert K, Hammer G (1998) Modelling leaf production and crop development in maize (Zea mays L.) after tassel initiation under diverse conditions of temperature and photoperiod. Field Crop Res 58:81-95

Boons-Prins E, De Koning G, Van Diepen C, de Vries F (1993) Crop specific simulation parameters for yield forecasting across the European Community, Simulation Reports CABO-TT 32. CABO-DLO, DLO Winand Staring Centre, JRC, Wageningen

Bouwman L, Goldewijk KK, Van Der Hoek KW, Beusen AH, Van Vuuren DP, Willems J, Rufino MC, Stehfest E (2013) Exploring global changes in nitrogen and phosphorus cycles in agriculture induced by livestock production over the 1900-2050 period. Proc Natl Acad Sci 110:20882-20887

Brüssow K, Gornott C, Faße A, Grote U (2019) The link between smallholders' perception of climatic changes and adaptation in Tanzania. Clim Chang 157:545-563

Cairns JE, Hellin J, Sonder K, Araus JL, MacRobert JF, Thierfelder C, Prasanna BM (2013) Adapting maize production to climate change in sub-Saharan Africa. Food Security 5:345-360

Challinor AJ, Ewert F, Arnold S, Simelton E, Fraser E (2009) Crops and climate change: progress, trends, and challenges in simulating impacts and informing adaptation. J Exp Bot 60:2775-2789 
Challinor AJ, Watson J, Lobell DB, Howden S, Smith D, Chhetri N (2014) A meta-analysis of crop yield under climate change and adaptation. Nat Clim Chang 4:287-291

Chapoto A, Chabala LM, Lungu ON (2016) A long history of low productivity In Zambia: is it time to do away with blanket recommendations. Working Paper 110, Indaba Agricultural Research Institute (IAPRI), Lusaka

Chen X, Strokal M, Kroeze C, Supit I, Wang M, Ma L, Chen X, Shi X (2020) Modeling the contribution of crops to nitrogen pollution in the Yangtze River. Environ Sci Technol 54:11929-11939

Chikowo DR (2016) Application of the GYGA approach to Zambia

Collins W, Bellouin N, Doutriaux-Boucher M, Gedney N, Halloran P, Hinton T, Hughes J, Jones C, Joshi M, Liddicoat S (2011) Development and evaluation of an earth-system model-HadGEM2. Geosci Model Dev Discuss 4:997-1062

Craufurd PQ, Wheeler TR (2009) Climate change and the flowering time of annual crops. J Exp Bot 60:25292539

Crespo O, Hachigonta S, Tadross M (2011) Sensitivity of southern African maize yields to the definition of sowing dekad in a changing climate. Clim Chang 106:267-283

Dale A, Fant C, Strzepek K, Lickley M, Solomon S (2017) Climate model uncertainty in impact assessments for agriculture: a multi-ensemble case study on maize in sub-Saharan Africa. Earth's Future 5:337-353

de Wit A, Boogaard H, Fumagalli D, Janssen S, Knapen R, van Kraalingen D, Supit I, van der Wijngaart R, van Diepen K (2019) 25 years of the WOFOST cropping systems model. Agric Syst 168:154-167

de Wit A, Boogaard H, Supit I, van den Berg M (2020) System description of the WOFOST 7.2, cropping systems model. Wageningen Environmental Research

Déqué M, Calmanti S, Christensen OB, Aquila AD, Maule CF, Haensler A, Nikulin G, Teichmann C (2017) A multi-model climate response over tropical Africa at+ 2 C. Clim Serv 7:87-95

MZSGS D (2005) Special report: FAO/WFP crop and food supply assessment mission to Zambia. In: Sackett HJM (ed)

Droppers B, Supit I, Van Vliet MT, Ludwig F (2021) Worldwide water constraints on attainable irrigated production for major crops. Environ Res Lett 16:055016

Dufresne J-L, Foujols M-A, Denvil S, Caubel A, Marti O, Aumont O, Balkanski Y, Bekki S, Bellenger H, Benshila R (2013) Climate change projections using the IPSL-CM5 Earth System Model: from CMIP3 to CMIP5. Clim Dyn 40:2123-2165

Dunne JP, John JG, Adcroft AJ, Griffies SM, Hallberg RW, Shevliakova E, Stouffer RJ, Cooke W, Dunne KA, Harrison MJ (2012) GFDL's ESM2 global coupled climate-carbon earth system models. Part I: physical formulation and baseline simulation characteristics. J Clim 25:6646-6665

Dunne JP, John JG, Shevliakova E, Stouffer RJ, Krasting JP, Malyshev SL, Milly P, Sentman LT, Adcroft AJ, Cooke W (2013) GFDL's ESM2 global coupled climate-carbon earth system models. Part II: carbon system formulation and baseline simulation characteristics. J Clim 26:2247-2267

Edmonds DE, Abreu SL, West A, Caasi DR, Conley TO, Daft MC, Desta B, England BB, Farris CD, Nobles TJ (2009) Cereal nitrogen use efficiency in sub Saharan Africa. J Plant Nutr 32:2107-2122

Engelbrecht F, Adegoke J, Bopape M-J, Naidoo M, Garland R, Thatcher M, McGregor J, Katzfey J, Werner M, Ichoku C (2015) Projections of rapidly rising surface temperatures over Africa under low mitigation. Environ Res Lett 10:085004

Engelbrecht F, McGregor J, Engelbrecht C (2009) Dynamics of the Conformal-Cubic Atmospheric Model projected climate change signal over southern Africa. Int J Climatol 29:1013-1033

Falconnier GN, Corbeels M, Boote KJ, Affholder F, Adam M, MacCarthy DS, Ruane AC, Nendel C, Whitbread AM, Justes É (2020) Modelling climate change impacts on maize yields under low nitrogen input conditions in sub-Saharan Africa. Glob Chang Biol 26:5942-5964

Faostat F (2020) Statistical databases. Food and Agriculture Organization of the United Nations

Fauchereau N, Trzaska S, Rouault M, Richard Y (2003) Rainfall variability and changes in southern Africa during the 20th century in the global warming context. Nat Hazards 29:139-154

Foley JA, Ramankutty N, Brauman KA, Cassidy ES, Gerber JS, Johnston M, Mueller ND, O'Connell C, Ray DK, West PC (2011) Solutions for a cultivated planet. Nature 478:337

Hempel S, Frieler K, Warszawski L, Schewe J, Piontek F (2013) A trend-preserving bias correction-the ISI-MIP approach. Earth Syst Dyn 4:219-236

Hengl T, Heuvelink GB, Kempen B, Leenaars JG, Walsh MG, Shepherd KD, Sila A, MacMillan RA, de Jesus JM, Tamene L (2015) Mapping soil properties of Africa at $250 \mathrm{~m}$ resolution: random forests significantly improve current predictions. PLoS One 10:e0125814

Hoffman AL, Kemanian AR, Forest CE (2018) Analysis of climate signals in the crop yield record of subSaharan Africa. Glob Chang Biol 24:143-157

IPCC (2013) The physical science basis. Contribution of working group I to the fifth assessment report of the intergovernmental panel on climate change. Cambridge University Press, United Kingdom and New York, NY, USA 
IPCC (2014) Impacts, Adaptation, and Vulnerability. Part B: Regional Aspects. Contribution of Working Group II to the Fifth Assessment Report of the Intergovernmental Panel on Climate Change. Cambridge University Press, Cambridge, United Kingdom and New York, NY, USA

International Food Policy Research Institute (2019) Global spatially-disaggregated crop production statistics data for 2010 version 2.0, vol V4. Harvard Dataverse. https://doi.org/10.7910/DVN/PRFF8V

Jain S (2007) An empirical economic assessment of impacts of climate change on agriculture in Zambia. The World Bank

Johnston A, Bruulsema T (2014) 4R nutrient stewardship for improved nutrient use efficiency. Procedia Eng 83: 365-370

Karapinar B, Özertan G (2020) Yield implications of date and cultivar adaptation to wheat phenological shifts: a survey of farmers in Turkey. Clim Chang 158:453-472

Kotir JH (2011) Climate change and variability in Sub-Saharan Africa: a review of current and future trends and impacts on agriculture and food security. Environ Dev Sustain 13:587-605

Kruger AC, Shongwe S (2004) Temperature trends in South Africa: 1960-2003. Int J Climatol 24:1929-1945

Lassaletta L, Billen G, Grizzetti B, Anglade J, Garnier J (2014) 50 year trends in nitrogen use efficiency of world cropping systems: the relationship between yield and nitrogen input to cropland. Environ Res Lett 9:105011

Leakey AD (2009) Rising atmospheric carbon dioxide concentration and the future of C4 crops for food and fuel. Proc R Soc B Biol Sci 276:2333-2343

Liang S, Li Y, Zhang X, Sun Z, Sun N, Duan Y, Xu M, Wu L (2018) Response of crop yield and nitrogen use efficiency for wheat-maize cropping system to future climate change in northern China. Agric For Meteorol $262: 310-321$

Liu Z, Hubbard KG, Lin X, Yang X (2013) Negative effects of climate warming on maize yield are reversed by the changing of sowing date and cultivar selection in Northeast China. Glob Chang Biol 19:3481-3492

Liu Z, Yang X, Hubbard KG, Lin X (2012) Maize potential yields and yield gaps in the changing climate of northeast China. Glob Chang Biol 18:3441-3454

Lobell DB, Bänziger M, Magorokosho C, Vivek B (2011a) Nonlinear heat effects on African maize as evidenced by historical yield trials. Nat Clim Chang 1:42-45

Lobell DB, Burke MB (2008) Why are agricultural impacts of climate change so uncertain? The importance of temperature relative to precipitation. Environ Res Lett 3:034007

Lobell DB, Cassman KG, Field CB (2009) Crop yield gaps: their importance, magnitudes, and causes. Annu Rev Environ Resour 34

Lobell DB, Field CB (2007) Global scale climate-crop yield relationships and the impacts of recent warming. Environ Res Lett 2:014002

Lobell DB, Schlenker W, Costa-Roberts J (2011b) Climate trends and global crop production since 1980. Science 333:616-620

Love D, Twomlow S, Mupangwa W, van der Zaag P, Gumbo B (2006) Implementing the millennium development food security goals-challenges of the southern African context. Phys Chem Earth Parts A/B/ C 31:731-737

Makondo CC, Thomas DS (2020) Seasonal and intra-seasonal rainfall and drought characteristics as indicators of climate change and variability in Southern Africa: a focus on Kabwe and Livingstone in Zambia. Theor Appl Climatol:1-14

Maúre G, Pinto I, Ndebele-Murisa M, Muthige M, Lennard C, Nikulin G, Dosio A, Meque A (2018) The southern African climate under $1.5 \mathrm{C}$ and $2 \mathrm{C}$ of global warming as simulated by CORDEX regional climate models. Environ Res Lett 13:065002

New M, Hewitson B, Stephenson DB, Tsiga A, Kruger A, Manhique A, Gomez B, Coelho CA, Masisi DN, Kululanga E (2006) Evidence of trends in daily climate extremes over southern and west Africa. J Geophys Res-Atmos 111

Nikulin G, Lennard C, Dosio A, Kjellström E, Chen Y, Hänsler A, Kupiainen M, Laprise R, Mariotti L, Maule CF (2018) The effects of 1.5 and 2 degrees of global warming on Africa in the CORDEX ensemble. Environ Res Lett 13:065003

Nissan H, Goddard L, de Perez EC, Furlow J, Baethgen W, Thomson MC, Mason SJ (2019) On the use and misuse of climate change projections in international development. Wiley Interdiscip Rev Clim Chang 10: e579

Njoroge S, Schut AG, Giller KE, Zingore S (2017) Strong spatial-temporal patterns in maize yield response to nutrient additions in African smallholder farms. Field Crop Res 214:321-330

Parent B, Tardieu F (2012) Temperature responses of developmental processes have not been affected by breeding in different ecological areas for 17 crop species. New Phytol 194:760-774

Pasley HR, Camberato JJ, Cairns JE, Zaman-Allah M, Das B, Vyn TJ (2020) Nitrogen rate impacts on tropical maize nitrogen use efficiency and soil nitrogen depletion in eastern and southern Africa. Nutr Cycl Agroecosyst:1-12 
Peichl M, Thober S, Samaniego L, Hansjürgens B, Marx A (2019) Climate impacts on long-term silage maize yield in Germany. Sci Rep 9:1-12

Pinto I, Lennard C, Tadross M, Hewitson B, Dosio A, Nikulin G, Panitz H-J, Shongwe ME (2016) Evaluation and projections of extreme precipitation over southern Africa from two CORDEX models. Clim Chang 135: 655-668

Ray DK, Gerber JS, MacDonald GK, West PC (2015) Climate variation explains a third of global crop yield variability. Nat Commun 6:1-9

Richards R, Hunt J, Kirkegaard J, Passioura J (2014) Yield improvement and adaptation of wheat to waterlimited environments in Australia — a case study. Crop and Pasture Science 65:676-689

Rurinda J, van Wijk MT, Mapfumo P, Descheemaeker K, Supit I, Giller KE (2015) Climate change and maize yield in southern Africa: what can farm management do? Glob Chang Biol 21:4588-4601

Sadras V, Cassman K, Grassini P, Bastiaanssen W, Laborte A, Milne A, Sileshi G, Steduto P (2015) Yield gap analysis of field crops: Methods and case studies

Sánchez B, Rasmussen A, Porter JR (2014) Temperatures and the growth and development of maize and rice: a review. Glob Chang Biol 20:408-417

Sandal SK, Suri V, Dhiman A (2008) Validation of fertilizer adjustment equations based on yield target concept and complimentary use of organic and biofertilizers along with inorganic fertilizers in rainfed maize (Zea mays): wheat (Triticum aestivum) system in wet temperate zone of Himachal Pradesh. Indian J Agric Sci 78: 490-494

Schlenker W, Lobell DB (2010) Robust negative impacts of climate change on African agriculture. Environ Res Lett 5:014010

Schlenker W, Roberts MJ (2009) Nonlinear temperature effects indicate severe damages to US crop yields under climate change. Proc Natl Acad Sci 106:15594-15598

Schulzweida U (2018) Climate data operators (CDO) user guide. Version

Sherene T, Santhi R, Kavimani R, Bharathi Kumar K (2016) Integrated fertilizer prescriptions for transgenic cotton hybrids under rainfed situation through inductive cum targeted yield model on vertisol. Commun Soil Sci Plant Anal 47:1951-1960

Shibu M, Leffelaar P, Van Keulen H, Aggarwal P (2010) LINTUL3, a simulation model for nitrogen-limited situations: application to rice. Eur J Agron 32:255-271

Silva JV, Giller KE (2021) Grand challenges for the 21st century: what crop models can and can't (yet) do. J Agric Sci:1-12

Singh M, Singh R, Dixit M (2004) Fertilizer prescription based on specific yield of barley (Hordeum vulgare). Annals of Biology (India)

Supit I, Van Diepen C, Boogaard H, Ludwig F, Baruth B (2010) Trend analysis of the water requirements, consumption and deficit of field crops in Europe. Agric For Meteorol 150:77-88

Supit I, Van Diepen C, De Wit A, Wolf J, Kabat P, Baruth B, Ludwig F (2012) Assessing climate change effects on European crop yields using the crop growth monitoring system and a weather generator. Agric For Meteorol 164:96-111

Van Diepen CV, Wolf J, Van Keulen H, Rappoldt C (1989) WOFOST: a simulation model of crop production. Soil Use Manag 5:16-24

van Heemst H (1988) Plant Data Values Required for Simple Crop Growth Simulation Models: Review and Bibliography (Simulation Report CABO-TT nr. 17). Centre for Agrobiological Research and Agricultural University, Wageningen, the Netherlands

Van Ittersum MK, Cassman KG, Grassini P, Wolf J, Tittonell P, Hochman Z (2013) Yield gap analysis with local to global relevance-a review. Field Crop Res 143:4-17

Van Ittersum MK, Van Bussel LG, Wolf J, Grassini P, Van Wart J, Guilpart N, Claessens L, de Groot H, Wiebe K, Mason-D'Croz D (2016) Can sub-Saharan Africa feed itself? Proc Natl Acad Sci 113:14964-14969

van Vuuren DP, Carter TR (2014) Climate and socio-economic scenarios for climate change research and assessment: reconciling the new with the old. Clim Chang 122:415-429

Veldkamp W (1987) Reconnaissance-semi-detailed semi-quantified land evaluation system for non-irrigated (rainfed) agricultural. Department of Agriculture

Warnatzsch EA, Reay DS (2020) Assessing climate change projections and impacts on Central Malawi's maize yield: the risk of maladaptation. Sci Total Environ 711:134845

Watanabe S, Hajima T, Sudo K, Nagashima T, Takemura T, Okajima H, Nozawa T, Kawase H, Abe M, Yokohata T (2011) MIROC-ESM 2010: model description and basic results of CMIP5-20c3m experiments. Geosci Model Dev 4:845

Woldemeskel F, Sharma A, Sivakumar B, Mehrotra R (2014) A framework to quantify GCM uncertainties for use in impact assessment studies. J Hydrol 519:1453-1465

Wolf J, Ouattara K, Supit I (2015) Sowing rules for estimating rainfed yield potential of sorghum and maize in Burkina Faso. Agric For Meteorol 214:208-218 
Wolf J, Van Diepen C, van Immerzeel C (1987) Monitoring agro-ecological resources using remote sensing and simulation (MARS-project). In: A study on the limitations to maize production in Zambia using simulation models and a geographic information system. Centre for World Food Studies, Wageningen

Xu X, He P, Pampolino MF, Chuan L, Johnston AM, Qiu S, Zhao S, Zhou W (2013) Nutrient requirements for maize in China based on QUEFTS analysis. Field Crop Res 150:115-125

Xu Z, Guan Z, Jayne TS, Black R (2009) Factors influencing the profitability of fertilizer use on maize in Zambia. Agric Econ 40:437-446

Yang Y, Timlin DJ, Fleisher DH, Lokhande SB, Chun JA, Kim S-H, Staver K, Reddy V (2012) Nitrogen concentration and dry matter accumulation in maize crop: assessing maize nitrogen status with an allometric function and a chlorophyll meter. Commun Soil Sci Plant Anal 43:1563-1575

Yerokun OA (2008) Chemical characteristics of phosphorus in some representative benchmark soils of Zambia. Geoderma 147:63-68

Yerokun OA, Chirwa M (2014) Soil and foliar application of Zinc to maize and wheat grown on a Zambian Alfisol. Afr J Agric Res 9:963-970

Zhao J, Yang X, Dai S, Lv S, Wang J (2015) Increased utilization of lengthening growing season and warming temperatures by adjusting sowing dates and cultivar selection for spring maize in Northeast China. Eur J Agron 67:12-19

Zinyengere N, Crespo O, Hachigonta S (2013) Crop response to climate change in southern Africa: a comprehensive review. Glob Planet Chang 111:118-126

Publisher's note Springer Nature remains neutral with regard to jurisdictional claims in published maps and institutional affiliations.

\section{Affiliations}

\section{Siatwiinda M. Siatwiinda ${ }^{1,2,3} \cdot$ Iwan Supit $^{2} \cdot$ Bert van Hove $^{2,4} \cdot$ Olusegun Yerokun $^{5} \cdot$ Gerard H. $\operatorname{Ros}^{1} \cdot$ Wim de Vries ${ }^{1}$}

1 Environmental Systems Analysis Group, Wageningen University, PO Box 47, 6700 AA Wageningen, The Netherlands

2 Water Systems and Global Change Group, Wageningen University, PO Box 47, 6700 AA Wageningen, The Netherlands

3 School of Agriculture and Natural Resources, Mulungushi University, PO Box 80415, Kabwe, Zambia

4 Meteorology and Air Quality group, Wageningen University, PO Box 47, 6700 AA Wageningen, The Netherlands

5 Formerly, Mulungushi University, Kabwe, Zambia 